KEYWORDS

Exports

Manufactures

Econometric models

Labour productivity

Economic policy

Mexico

Víctor M. Cuevas

Research Professor, Department

of Economics, Autonomous

Metropolitan University (UAM)

and member of the National

Researchers System

-o victorcuevasahumada $a$ yahoo.com.mx

CEPAL REVIEW 102 - DECEMBER 2010

\section{The dynamics of Mexican manufacturing exports}

\author{
Victor M. Cuevas
}

$\mathrm{T}$

his article evaluates several of the determinants of Mexican manufacturing exports, using two complementary econometric methods: a structural ARIMA model, which makes it possible to estimate elasticities; and a generalized VAR model, which provides a fully dynamic perspective by estimating impulse response functions. As some of the findings are robust to changes in the econometric methodology used, the article reaches the following conclusions. First, manufacturing exports are positively related to labour productivity and external demand; so the adverse effects of an international recession on Mexican exports could, to some extent, be offset by raising worker productivity. Second, real exchange-rate depreciation does not increase manufacturing exports, but actually reduces them, at least in the short run. These findings are consistent with the idea that a real depreciation not only affects demand, but also generates strong supply-side effects. 


\section{I}

\section{Introduction}

This article evaluates several of the variables that determine Mexico's manufacturing exports, using two complementary econometric methods: a structural Autoregressive Integrated Moving Average (ARIMA) model to estimate elasticities; and a Generalized Vector Autoregressive (GVAR) model, which makes it possible to estimate the dynamic responses of manufacturing exports to different types of shock. ${ }^{1}$ Accordingly, both univariate and multivariate time series analyses are used to obtain two different perspectives on the factors driving manufacturing exports.

Several previous empirical studies have shown that exports are influenced not only by relative prices and external demand, but also by domestic demand and supply-side factors. In that context, this paper concludes that increased labour productivity and external demand expansions both have a significant impact on the growth of manufactured exports. Moreover, the evidence provided here suggests that a real exchange-rate depreciation could reduce the volume of exports in the short term, rather than increase it. A plausible explanation for this atypical result is that real currency depreciation generates two opposing effects, especially in developing countries: it makes their exports cheaper in terms of foreign currency; but it also raises the local-currency cost of imported intermediate inputs. The net effect on Mexico's international competitiveness appears to be negative, at least in the short term. Lastly, we present empirical results showing that strategic investment and production decisions are driven by the firm's desire to grow its exports.

An important economic-policy implication of this is that the adverse effects of an international recession on Mexican exports could, to some extent, be offset through higher labour productivity. Moreover, a comprehensive and coherent package designed to enhance labour productivity could prove more effective in stimulating manufacturing exports than a depreciation of the real exchange rate.

The rest of this paper is organized as follows. Section II briefly reviews the recent literature. Section III describes the model and the data set. Section IV conducts the integration and co-integration analyses. Sections V and VI present the estimates obtained from the univariate and multivariate time-series models, respectively; while Section VII summarizes the findings and examines the economic policy implications. Section VIII sets out the conclusions.

\section{II}

\section{Literature review}

The use of new econometric methods has revived interest in the short- and long-term determinants of exports. In general, export functions are usually specified under three basic approaches: (i) gravity models of trade, (ii) theoretical demand models, and (iii) theoretical models that combine demand-

$\square$ The author gratefully acknowledges financial support for this research from the National Science and Technology Council (CONACYT), and the comments and suggestions made by an anonymous referee.

${ }^{1}$ The GVAR method produces empirical evidence that is independent of the ordering of the equations, which is a major improvement over traditional recursive VAR models. and supply-side variables. Although this is not an exhaustive classification, it provides the background needed to perform the empirical analysis and interpret the key findings.

The gravity model of trade has been relatively successful in modelling bilateral trade flows between countries since the early 1960s. Pioneering research in this field includes the work of Isard (1954), Tinbergen (1962) and Pöyhönen (1963). In the canonical specification of the gravity model, exports from one country to another are posited as an increasing function of economy size, measured by gross domestic product (GDP), and as a decreasing function of 
transport costs, measured by the distance between the two countries.

Over the years, the inclusion of other variables, such as population, common language and shared borders, has given rise to an "augmented gravity model". Two recent studies that use this version of the model are Boisso and Ferrantino (1997), and Bayoumi and Eichengreen (1997). Another line of research is represented by Bergstrand (1985) and Summary (1989), among others, who have improved the explanatory power of the gravity equation by adding variables such as prices and exchange rates, which are not directly related to geography or spatial factors.

In contrast, under the theoretical demand model, the volume of exports basically depends on the real exchange rate and the foreign income level, as measured by economic activity abroad or the physical volume of imports in the country's main trading partners. Two of the best known studies using this approach are Reinhart (1995), and Senhadji and Montenegro (1998).

Based on a sample of 12 developing countries (including Mexico), Reinhart (1995) shows that exports are more responsive to changes in external demand than to variations in relative prices. Senhadji and Montenegro (1998) enlarge the sample to encompass 53 countries, including both developing and industrialized economies, and they estimate long-term income- and price-elasticities of export demand at roughly 1.5 and -1 , respectively.

Despite their popularity and widespread use, standard demand models have not been free from criticism. In particular, Riedel (1988) shows that neglecting supply-side factors leads to biased estimates of export-demand elasticities. As a result, some empirical models started to include variables relating to the supply of exports and the domestic demand for exportable goods, in addition to the traditional demand-side variables. This new strand of literature includes several papers focusing specifically on developing economies. In the case of Argentina, Catao and Falsetti (2002) show that manufacturing exports respond significantly to economic activity in Brazil, Uruguay and Paraguay (Argentina's trading partners in MERCOSUR), and also to the real exchange rate of the Argentine peso against the Brazilian real. These authors also provide evidence that an increase in net aggregate investment would stimulate manufacturing exports, while a rise in domestic consumption would have the opposite effect.

Berrettoni and Castresana (2007) analyse the impact of the real exchange rate, exchange-rate volatility, external demand and capacity utilization (among other explanatory variables) on Argentina's industrial manufacturing exports. They find that exchange-rate volatility is negatively related to exports, while external demand influences exports more than the real exchange rate.

For the Mexican economy, Cuevas (2008) shows that manufacturing exports are affected not only by changes in the real exchange rate and the level of output in the United States, but also by improvements in labour productivity. Similarly, Padilla and Juárez (2006) highlight the essential role of training in making the Mexican manufacturing sector more competitive. As that study measures competitiveness in the Mexican manufacturing sector through changes in total factor productivity, ${ }^{2}$ a plausible hypothesis is that training enhances competitiveness (as measured by productivity), which, in turn, raises the level of manufacturing exports.

Lastly, a number of studies relate exports to other variables in developing economies. For example, Goldberg and Klein (1997) identify several positive effects of foreign direct investment (FDI) on exports in Latin American countries, ${ }^{3}$ whereas Mbale and Golub (2002) show that a reduction in unit labour costs raises manufacturing exports in Senegal. Thus, according to these authors, labour productivity needs to outpace wages in order to stimulate export growth.

In brief, the econometric evidence suggests that exports depend on a variety of variables, including those specifically related to geography and spatial factors. Moreover, there is a basic consensus that exports are more responsive to external demand than to real exchange-rate adjustments. Lastly, the empirical evidence supports the claim that export volume depends not only on relative prices and foreign income, but also on the domestic demand for exportable goods and supply-side variables such as labour productivity, wages and fdi (Riedel, 1998).

\footnotetext{
2 The competitiveness of a firm, industry or nation depends on numerous factors (such as wages, productivity, technological progress, infrastructure, human capital, and the like); and it can be defined and measured in a variety of ways. Given the difficulty of achieving general agreement on this issue, many authors have opted to define and even measure competitiveness on the basis of its results or consequences. For instance, according to Naby and Luthria (2002) competitiveness is the country's ability to maintain and expand its foreign-market share.

3 There are two plausible explanations for this positive relation: first, the host nations are used as a platform to export a variety of goods to industrial countries; and second, FDI tends to promote broader-based trade in intermediate inputs between the parent company and subsidiary producers.
} 


\section{III}

\section{The model}

The aim of this article is to assess the impact of various key variables on Mexican manufacturing exports, with a view to formulating policy recommendations. The choice of regressors has been determined by data availability, previous econometric work and economic theory. In principle the following expanded export equation will be estimated: ${ }^{4}$

$$
X=f(v, W, Q, E D, F D I, R, C U, O P)
$$

where:

$X=$ Volume of manufacturing exports.

$v=$ Labour productivity in manufacturing industry.

$W=$ Average real hourly wages in manufacturing industry.

$Q=$ Real effective exchange rate. This is a multilateral exchange rate, since it reflects changes in Mexico's international competitiveness, based on price indices in 111 of its trading partners.

$E D=$ External demand for Mexican manufacturing exports. After performing various tests and estimations, it was decided use total United States manufacturing imports as a proxy for Mexico's external demand. ${ }^{5}$ $F D I=$ Foreign direct investment in the manufacturing sector, measured in real terms.

$R=$ Cost of domestic credit as measured by the weighted average of real interest rates on commercial paper.

$C U=$ Percentage capacity utilization in manufacturing industry.

$O P=$ Occupied personnel in manufacturing industry.

The variables $X, v, W, Q, E D$, and $O P$ and are measured as indices. ${ }^{6}$ The next step was to gather

\footnotetext{
${ }^{4}$ This equation will later be subjected to a battery of specification tests, which will help identify potentially redundant and omitted variables.

5 The external demand for Mexican manufactures can be adequately proxied by this variable, since $79.86 \%$ of Mexico's non-oil commodity exports went to the United States in 2008. Moreover, Mexican exports accounted for $10.28 \%$ of United States imports from the rest of the world in that year, making Mexico the United States' third most important supplier after China and Canada (Source: Banco de México, Annual Report 2008, pp. 47 and 48).

6 The remaining variables are measured as previously stated.
}

quarterly data for each variable from January 1998 to December $2008,{ }^{7}$ during which period, in particular, the two models are stable and their residuals have well-behaved statistical properties. The data for all variables were seasonally adjusted using the X12-ARIMA procedure. Lastly, all series - except for the interest rate and capacity utilization - are expressed as natural logarithms.

In section III, equation (1) is estimated as a standard linear regression and then re-specified as a structural ARIMA model, once potentially redundant and/or omitted variables have been properly identified and residual tests performed. A structural ARIMA model can also be referred to as an ARIMAX (autoregressive integrated moving-average model with exogenous variables), since: (i) it differentiates the dependent variable (and the explanatory variables) by order of integration; (ii) it reflects a structural relation between the dependent and explanatory variables; and (iii) it includes autoregressive (AR) and moving-average (MA) terms to satisfactorily model the error process.

In section IV, a GVAR model is used to assess to what extent, if any, the empirical evidence is sensitive to changes in the econometric methodology applied. The use of both univariate and multivariate econometric techniques will allow two different perspectives of the response of manufacturing exports to changes in their basic determinants, such as labour productivity $(v)$, the real exchange rate $(Q)$ and external demand $(E D)$.

Installed capacity utilization $(C U)$ and Occupied personnel $(O P)$ are used as control variables. ${ }^{8}$ Percentage installed capacity utilization helps to prevent a number of distortionary effects on the dependent variable, such as those generated when the gap between actual and potential output (in the manufacturing sector) narrows or widens. As a result, parameter estimates are more likely to discriminate between legitimate increases in manufacturing exports, reflecting higher labour productivity for

\footnotetext{
7 See Appendix 1 for a detailed description of data sources and measurement units.

${ }^{8}$ Relevant control variables are usually included in an equation to reduce the risk of biased parameter estimates owing to omittedvariable problems.
} 
instance, and spurious ones resulting from lower-thanexpected domestic demand. Similarly, the employee index is intended to prevent the parameter estimates associated with labour productivity and wages from capturing the effects of possible mass layoffs, which could be triggered by trade liberalization policies, the acquisition of physical capital or the introduction of new technologies. See Jiménez et al (1998), Catao and Falsetti (2002) and Berretoni and Castresana (2007) for further details on this.

\section{IV}

\section{Integration and co-integration analysis}

Given that every unit root and stationarity test has arguments for and against, three different standard tests were used: the augmented Dickey-Fuller test (ADF, 1979), the Phillips-Perron test (PP, 1988), and the Kwiatkowski, Phillips, Schmidt, and Shin test (KPSS, 1992). In testing for unit roots (or for the presence of stationarity), an important issue is whether to include a constant and a linear trend in the test equation, or a constant only. ${ }^{9}$ To resolve this matter satisfactorily the Hamilton procedure was used (Hamilton, $1994 \mathrm{p}$. 501), which consists of choosing the specification that provides the most realistic description of the data, under both the null and the alternative hypotheses. Each test equation was also subjected to a battery of $F$-type tests, which are based on the critical values that Dickey and Fuller (1981) and Dickey et al (1986) developed for that purpose. ${ }^{10}$ The basic test results are reported in table 1.

As is well known, the ADF and PP tests contrast the null hypothesis of a unit root against the alternative hypothesis of stationarity, whereas the KPSS test compares the null hypothesis of stationarity against the alternative of non-stationarity. The rationale for including a stationarity test such as KPSS is that a failure to reject a unit root hypothesis is sometimes due to the lack of power of the ADF and PP tests.

It is not uncommon for unit root and stationarity tests to yield conflicting results, so the available empirical evidence needs to be globally assessed. Thus, in addition to formal tests, the consistency of the correlogram of a given time series with stationarity needs to be considered. In general terms, the picture

\footnotetext{
9 The third possibility is to omit both, but the KPSS test cannot be performed without the constant term.

10 The null hypothesis of a unit root with no deterministic trend was tested against the alternative hypothesis of a stationary variable with a deterministic trend.
}

that emerges is that real FDI and the real interest rate are stationary (or $\mathrm{I}(0)$ ), whereas the other seven variables can reasonably be treated as integrated variables of order 1 (or I(1)) in levels, and stationary in terms of first differences. ${ }^{11}$ This conclusion can also be validated to some degree by analysing the behaviour of the residuals in the univariate and multivariate models, which tends to improve when FDI and the rate of interest are expressed in terms of levels while the other variables are expressed as first differences.

Having determined the order of integration of each variable, the question of whether the I(1) variables share a long-run relation then needs to be considered. If the $\mathrm{I}(1)$ variables were in fact cointegrated, one could consider removing FDI and the interest rate from the system (as these variables are stationary), to estimate a seven-variable Vector Error-Correction (VEC) model. The Johansen (1995) co-integration tests will be used to check whether the non-stationary variables are co-integrated. Johansen uses two types of likelihood-ratio (LR) test statistics in testing for co-integration: the trace statistic, denoted by $\lambda_{\text {trace }}$, and the largest eigenvalue statistic, denoted by $\lambda_{\text {max }}$. Although both are $L R$ statistics, they are not asymptotically distributed as a standard $\chi^{2}$ distribution under the null hypothesis. Consequently, the nonstandard critical values developed by MacKinnon, Haug and Michelis (1999) are used. The results of

\footnotetext{
11 Real FDI appears to be stationary for two reasons: (i) this particular variable does not display a clear growth trend in the 1998-2008 period, and (ii) its volatility does not seem to increase (or decrease) over time. By the same token, the tests performed consistently indicate that capacity utilization is a non-stationary (I(1)) variable. Although there are some atypical observations, neither their removal nor the use of moving-average filtering affects the outcome of the unit root and stationarity tests. Lastly, as shown below, the stability checks indicate that no structural change occurred during the sample period.
} 
TABLE 1

Unit root and stationarity tests, 1998-2008

\begin{tabular}{|c|c|c|c|c|c|}
\hline Variable & $\begin{array}{l}\text { Specification of the } \\
\text { test equation }\end{array}$ & $\begin{array}{l}\text { ADF test statistic } \\
\text { (Ho: unit root) }\end{array}$ & $\begin{array}{l}\text { PP test statistic } \\
\text { (Ho: unit root) }\end{array}$ & $\begin{array}{l}\text { KPSS test statistic } \\
\text { (Ho: stationarity) }\end{array}$ & $\begin{array}{l}\text { Order of } \\
\text { Integration }\end{array}$ \\
\hline$X_{t}$ & $\mathrm{C}$ and $\mathrm{LT}$ & -1.97 & -1.97 & 0.11 & $\mathrm{I}(1)$ or $\mathrm{I}(0)$ \\
\hline$\Delta X_{t}$ & $\mathrm{C}$ & $-4.66^{* *}$ & $-4.63^{* *}$ & 0.11 & $\mathrm{I}(0)$ \\
\hline$v_{t}$ & $\mathrm{C}$ and $\mathrm{LT}$ & -1.75 & -1.92 & 0.13 & $\mathrm{I}(1)$ or $\mathrm{I}(0)$ \\
\hline$\Delta v_{t}$ & $\mathrm{C}$ & $-6.53 * *$ & $-6.45^{* *}$ & 0.28 & $\mathrm{I}(0)$ \\
\hline$W_{t}$ & $\mathrm{C}$ and $\mathrm{LT}$ & 1.24 & 0.54 & $0.23 * *$ & $\mathrm{I}(1)$ \\
\hline$\Delta W_{t}$ & $\mathrm{C}$ & $-5.97 * *$ & $-6.30 * *$ & 0.44 & $\mathrm{I}(0)$ \\
\hline$Q_{t}$ & $\mathrm{C}$ & -1.90 & -2.84 & 0.34 & $\mathrm{I}(1)$ or $\mathrm{I}(0)$ \\
\hline$\Delta Q_{t}$ & $\mathrm{C}$ & $-4.89 * *$ & $-4.97 * *$ & $0.52 *$ & $\mathrm{I}(1)$ or $\mathrm{I}(0)$ \\
\hline$\Delta Q_{t}$ & None & $-4.95 * *$ & $-5.02 * *$ & N.D. & $\mathrm{I}(0)$ \\
\hline$E D_{t}$ & $\mathrm{C}$ and $\mathrm{LT}$ & -3.31 & -2.13 & 0.11 & $\mathrm{I}(1)$ or $\mathrm{I}(0)$ \\
\hline$\Delta E D_{t}$ & $\mathrm{C}$ & $-4.35^{* *}$ & $-4.99 * *$ & 0.06 & $\mathrm{I}(0)$ \\
\hline$F D I_{t}$ & $\mathrm{C}$ & $-6.07 * *$ & $-6.08 * *$ & 0.22 & $\mathrm{I}(0)$ \\
\hline$R_{t}$ & $\mathrm{C}$ & $-3.43^{* *}$ & $-4.65 * *$ & $0.50^{*}$ & $\mathrm{I}(1)$ or $\mathrm{I}(0)$ \\
\hline$\Delta R_{t}$ & $\mathrm{C}$ & $-7.40 * *$ & $-7.96^{* *}$ & 0.40 & $\mathrm{I}(0)$ \\
\hline$\Delta R_{t}$ & None & $-7.58 * *$ & $-7.88 * *$ & N.D. & $\mathrm{I}(0)$ \\
\hline$C U_{t}$ & $\mathrm{C}$ & -1.08 & -1.19 & $0.57^{*}$ & $\mathrm{I}(1)$ \\
\hline$\Delta C U_{t}$ & $\mathrm{C}$ & $-6.18 * *$ & $-6.18 * *$ & 0.16 & $\mathrm{I}(0)$ \\
\hline$\Delta C U_{t}$ & None & $-6.25^{* *}$ & $-6.28 * *$ & N.D. & $\mathrm{I}(0)$ \\
\hline$O P_{t}$ & $\mathrm{C}$ & -1.07 & -0.52 & $0.61^{*}$ & $\mathrm{I}(1)$ \\
\hline$\Delta O P_{t}$ & $\mathrm{C}$ & -2.06 & -2.04 & 0.33 & $\mathrm{I}(1)$ or $\mathrm{I}(0)$ \\
\hline$\Delta O P_{t}$ & None & $-1.97 *$ & $-1.97 *$ & N.D. & $\mathrm{I}(0)$ \\
\hline
\end{tabular}

Source: Author's estimations on the basis of quarterly data obtained from the databases of the National Institute of Statistics, Geography and Information of Mexico (INEGI), The Bank of Mexico, the United States Census Bureau and the consumer price index published by the United States Bureau of Labour Statistics, of the Department of Labor of the United States.

Notes.

ADF test: Augmented Dickey-Fuller test; pp: Phillips-Perron test; kpss: Kwiatkowski, Phillips, Schmidt and Shin test.

Ho: Null hypothesis.

C: Constant.

LT: Linear Trend.

- Asterisks * and ** denote rejection of the null hypothesis at the $5 \%$ and $1 \%$ significance levels, respectively.

- The symbols $\Delta$ and $\Delta^{2}$ are the first- and second-difference operators, respectively.

- The ADF and PP test results are based on Mackinnon (1996) critical values and their associated one-sided $p$-values. In the ADF tests, the Schwarz Information Criterion is used to determine the lag length of each test equation. In the PP tests we control the bandwidth using the Newey-West bandwidth selection method and the Bartlett kernel.

- The KPSS test results are based on the critical values proposed by Kwiatkowski, Phillips, Schmidt and Shin (1992). To control the bandwidth, we use the Newey-West bandwidth selection method and the Bartlett kernel.

Johansen's co-integration trace and largest eigenvalue tests are reported in tables 2 and 3, respectively.

As shown in tables 2 and 3 , these tests are done sequentially, starting at $r=0$ and ending at $r \leq k-1$, where $r$ is the number of co-integrating equations, and $k$ is the number of variables involved in the testing procedure. At the $5 \%$ significance level, the trace tests suggest that there are three co-integrating equations, whereas the largest eigenvalue tests suggest only two. ${ }^{12}$ Despite these results, a VEC model is not feasible in this particular case for two reasons. First and foremost,

12 An important distinction between the trace and largest eigenvalue statistic is that the latter is based on a more restrictive alternative hypothesis, which is meant to increase the power of the test. after performing different normalizations for the co-integrating vectors, the conclusion is that they are not identifiable. In other words, given the sign and magnitude of the various parameter estimates, all of the candidate co-integrating equations are clearly inconsistent with economic theory, so they cannot be used for valid inference. ${ }^{13}$ Secondly, under the Johansen methodology, manufacturing exports $(X)$ turn out to be weakly exogenous with respect to the "adjustment parameters", which means that, in a VEC model, this particular variable can even be

\footnotetext{
13 This problem remained after eradicating potentially redundant variables through likelihood ratio tests.
} 


\begin{tabular}{|c|c|c|c|}
\hline Null hypothesis & Alternative hypothesis & $\lambda_{\text {trace }}$-statistic & $5 \%$ critical value \\
\hline$r=0$ & $r \geq 1$ & $171.9232 *$ & 125.6154 \\
\hline$r \leq 1$ & $r \geq 2$ & $115.2237^{*}$ & 95.75366 \\
\hline$r \leq 2$ & $r \geq 3$ & $70.36657^{*}$ & 69.81889 \\
\hline$r \leq 3$ & $r \geq 4$ & 40.62333 & 47.85613 \\
\hline$r \leq 4$ & $r \geq 5$ & 24.06045 & 29.79707 \\
\hline$r \leq 5$ & $r \geq 6$ & 11.08441 & 15.49471 \\
\hline$r \leq 6$ & $r \geq 7$ & 0.391198 & 3.841466 \\
\hline
\end{tabular}

Source: Author's estimations on the basis of quarterly data obtained from the databases of the National Institute of Statistics, Geography and Information of Mexico (INEGI), The Bank of Mexico, the United States Census Bureau and the consumer price index published by the United States Bureau of Labor Statistics, of the Department of Labor of United States.

Notes:

- The letter $r$ stands for the number of co-integrating equations.

- An asterisk * denotes rejection of the null hypothesis at the 5\% significance level, given the critical values developed by MacKinnon, Haug and Michelis (1999).

- Trace tests indicate the existence of three co-integrating equations at the $5 \%$ significance level.

- The lag length of the VAR is 1 . A constant in the co-integrating space and a linear trend in the data space were included.

\begin{tabular}{|c|c|c|c|}
\hline Null hypothesis & Alternative hypothesis & $\lambda_{\max }$-statistic & $5 \%$ critical value \\
\hline$r=0$ & $r=1$ & $56.69948^{*}$ & 46.23142 \\
\hline$r \leq 1$ & $r=2$ & $44.85710^{*}$ & 40.07757 \\
\hline$r \leq 2$ & $r=3$ & 29.74324 & 33.87687 \\
\hline$r \leq 3$ & $r=4$ & 16.56288 & 27.58434 \\
\hline$r \leq 4$ & $r=5$ & 12.97604 & 21.13162 \\
\hline$r \leq 5$ & $r=6$ & 10.69321 & 14.26460 \\
\hline$r \leq 6$ & $r=7$ & 0.391198 & 3.841466 \\
\hline
\end{tabular}

Source: Author's estimations on the basis of quarterly data obtained from the databases of the National Institute of Statistics, Geography and Information of Mexico (INEGI), The Bank of Mexico, the United States Census Bureau and the consumer price index published by the United States Bureau of Labor Statistics, of the Department of Labor of the United States.

Notes:

- The letter $r$ stands for the number of co-integrating equations.

- An asterisk * denotes rejection of the null hypothesis at the 5\% significance level, given the critical values developed by MacKinnon, Haug and Michelis (1999).

- Largest eigenvalue tests indicate the existence of two co-integrating equations at the 5\% significance level.

- The lag length of the VAR is 1 . A constant in the co-integrating space and a linear trend in the data space were included.

removed from the system. Appendix 2 shows the weak exogeneity of this variable together with a brief technical explanation. ${ }^{14}$

14 For further details, see Johansen (1995) and Patterson (2000, chapter 15).
Under these circumstances, a stationary GVAR model will be estimated in section VI. This means that the $\mathrm{I}(1)$ variables will be expressed in first differences, thus making every variable in the system $\mathrm{I}(0)$. A stationary GVAR model is statistically appropriate for short-term economic analysis. 


\section{V}

\section{Univariate time-series analysis}

This section estimates a structural ARIMA model using least-squares algorithms, departing from an unadjusted regression equation, which in principle does not include autoregressive or moving average (ARMA) terms. The basic results are reported in table 4 .

As noted above, except for FDI and the interest rate, all variables seem to be non-stationary, so FDI and the interest rate will enter the regression equation in levels, while the rest of the variables will be expressed in first differences. Moreover, except for the interest rate and percentage capacity utilization, all variables are expressed in natural logarithms, so their estimated coefficients should be interpreted as elasticities.

It is worth noting that including irrelevant variables reduces efficiency, while excluding relevant variables yields biased parameter estimates. But before dealing with potential specification errors, it needs to be stressed that both labour productivity $\left(v_{t}\right)$ and export demand $\left(E D_{t}\right)$ have estimated coefficients that are positive and statistically significant at the $10 \%$ significance level. In contrast, the estimated coefficient of the real exchange rate is negative and statistically significant at the $5 \%$ level.

\section{Adjusted regression equation}

Several likelihood ratio tests for redundant and omitted variables were performed in an interactive process to make sure the final specification was appropriate. Although the primary strategy involved a generalto-specific search, several omitted-variables tests were performed to determine whether, and to what extent, any of the variables not originally considered contributed significantly to explaining the behaviour of manufacturing exports. The main candidate variables considered for possible inclusion were realexchange rate volatility and gross fixed investment, but they failed to achieve statistical significance either individually or jointly. Similarly, to identify potentially redundant variables, the individual and joint statistical significance of the regressors already included in equation (1) were checked. ${ }^{15}$

\footnotetext{
15 We also assessed alternative lag structures and interaction effects between the independent variables.
}

\begin{tabular}{|c|c|c|c|c|}
\hline \multicolumn{5}{|c|}{ Dependent variable: $\Delta X_{t}$} \\
\hline Variable & Coefficient & Standard error & t-Statistic & Probability value \\
\hline$\Delta v_{t}$ & 0.716876 & 0.384891 & 1.862545 & 0.0723 \\
\hline$\Delta W_{t}$ & -0.275609 & 0.243587 & -1.131462 & 0.2668 \\
\hline$\Delta Q_{t}$ & -0.226815 & 0.094223 & -2.407202 & 0.0224 \\
\hline$\Delta E D_{t}$ & 0.302333 & 0.151828 & 1.991284 & 0.0556 \\
\hline$F D I_{t}$ & -0.006458 & 0.010792 & -0.598433 & 0.5540 \\
\hline$R_{t}$ & 0.000538 & 0.001137 & 0.473169 & 0.6395 \\
\hline$\Delta C U_{t}$ & 0.008229 & 0.005243 & 1.569348 & 0.1271 \\
\hline$\triangle O P_{t}$ & 0.870729 & 0.593613 & 1.466829 & 0.1528 \\
\hline Intercept term & 0.022091 & 0.038190 & 0.578452 & 0.5673 \\
\hline Adjusted $R^{2}$ & 0.501665 & \multicolumn{2}{|c|}{ Standard error of regression } & 0.020093 \\
\hline DW statistic & 2.249753 & \multicolumn{2}{|c|}{ Probability value (F-statistic) } & 0.000172 \\
\hline
\end{tabular}

Source: Author's estimations on the basis of quarterly data obtained from the databases of the National Institute of Statistics, Geography and Information of Mexico (INEGI), The Bank of Mexico, the United States Census Bureau and the consumer price index published by the United States Bureau of Labor Statistics, of the Department of Labor of the United States. 
The general equation was thus gradually reduced to a range of specific equations, and the final model was chosen on the basis of diagnostic statistics and economic theory. Lastly, the procedure developed by Hannan and Rissanen (1982) was applied to identify a suitable ARIMA model for the regression residuals; and this eventually gave rise to a structural ARIMA $(1,1,1)$ model with four explanatory variables, which seems to be well-grounded for three major reasons: (i) the regression residuals display a "normal" white-noise process; (ii) the regression equation is stable; and (iii) explanatory power as measured by the adjusted $R^{2}$ rises considerably. Such a model can be represented as follows:

$\Delta X_{t}=b_{0}+b_{1} \Delta v_{t}+b_{2} \Delta Q_{t}+b_{3} \Delta E D_{t}+b_{4} \Delta O P_{t}+u_{t}$

where $u_{t}=\phi_{1} u_{t-1}+\varepsilon_{t}+\theta_{1} \varepsilon_{t-1}$ and $\varepsilon_{t}$ is a normal whitenoise process. Table 5 shows the basic estimation results.

The adjusted equation shows that the estimated coefficients for labour productivity and external demand are positive and statistically significant at the $5 \%$ and $1 \%$ levels, respectively. Assuming a variable's growth rate can be adequately proxied by its first difference, we could say that a one-percentage-point increase in the rate of labour productivity growth will raise the growth rate of manufacturing exports by 83 basis points ( 0.83 of a percentage point). Similarly, a one-percentage-point drop in the rate of growth of external demand will lower the manufacturing exports growth rate by 49 basis points. In view of these results, a coherent policy package designed to increase worker productivity might be effective in alleviating the negative effects of weaker external demand (resulting from an international recession) on Mexican manufacturing exports.

The tests also suggest that real exchange-rate depreciation may reduce the volume of exports in the short run. In other words, the estimated coefficient of the real exchange rate is negative and statistically significant at the $1 \%$ level. As noted above, this result is consistent with the notion that a real depreciation, especially in developing countries, produces two opposing effects: it makes exports cheaper in terms of foreign currency; but it also raises the local-currency cost of imported intermediate inputs. Consequently, international competitiveness might worsen if the latter effect dominates.

Lastly, the parameter associated with the number of employees occupied personnel is positive and significantly different from zero at the $1 \%$ level, thereby suggesting that manufacturing firms make a deliberate effort to sell their products abroad.

\section{Diagnostic tests}

A number of tests were done to ensure that the residuals from the adjusted regression equation were free from serial correlation, heteroscedasticity, autoregressive conditional heteroscedasticity (ARCH) and systematic departures from normality. Table 6 sets out the basic results for some of the tests performed.

TABLE 5

Adjusted equation for manufacturing exports

\begin{tabular}{|c|c|c|c|c|}
\hline \multicolumn{5}{|c|}{ Dependent variable: $\Delta X_{t}$} \\
\hline Variable & Coefficient & Standard error & $t$-Statistic & Probability value \\
\hline$\Delta v_{t}$ & 0.833277 & 0.314149 & 2.652487 & 0.0117 \\
\hline$\Delta Q_{t}$ & -0.193773 & 0.041048 & -4.720681 & 0.0000 \\
\hline$\Delta E D_{t}$ & 0.486660 & 0.099567 & 4.887755 & 0.0000 \\
\hline$\Delta O P_{t}$ & 1.277885 & 0.287783 & 4.440447 & 0.0001 \\
\hline Intercept term & 0.000771 & 0.002877 & 0.267881 & 0.7903 \\
\hline $\operatorname{AR}(1)$ & 0.428219 & 0.178590 & 2.397779 & 0.0217 \\
\hline $\operatorname{MA}(1)$ & -0.997398 & 0.125894 & -7.922543 & 0.0000 \\
\hline Adjusted $R^{2}$ & 0.636163 & \multicolumn{2}{|c|}{ Standard error of regression } & 0.018380 \\
\hline DW statistic & 2.015594 & \multicolumn{2}{|c|}{ Probability value ( $F$-statistic) } & 0.000000 \\
\hline
\end{tabular}

Source: Author's estimations on the basis of quarterly data obtained from the Institute of Statistics, Geography and Information of Mexico (INEGI), The Bank of Mexico, the United States Census Bureau and the consumer price index published by the United States Bureau of Labor Statistics, of the Department of Labor of the United States. 
As can be seen in table 6, the behavior of the residuals from the adjusted regression model is broadly consistent with normal white noise. In other words, the Lagrange multiplier (LM) test for serial correlation indicates the absence of serial correlation up to lag order five, ${ }^{16}$ whereas the White heteroscedasticity test shows that the errors are homoscedastic. Similarly, the ARCH test suggests that the magnitude of the residuals in the present is unrelated to their magnitude in the past; and, lastly, the outcome of the JarqueBera normality test rules out the presence of serious departures from normality.

To determine whether the adjusted manufacturing export equation remains unchanged throughout the

16 The correlogram of the residuals is also consistent with the absence of autocorrelation up to lag order 20. period, we used Chow's test with multiple break-points, the results of which are shown in table 7.

Probability values corresponding to the three test statistics (the $F$-, log-likelihood ratio and Wald statistics) show that the null hypothesis of "no structural change" is also far from being rejected, which means that the parameters of the model are stable across the four sub-samples obtained from the break-points designated in the data set.

Similarly, the ARIMA process of the estimated regression equation is stationary and invertible. Stationarity stems from the fact that the inverse root of the autoregressive component (AR(1)) lies within the unit circle, whereas invertibility arises from the fact that the inverse root of the moving-average component (MA(1)) lies within the unit circle. See table 8 for details.

TABLE 6

Diagnostic tests for the residuals of the adjusted regression equation, 1998-2008

\begin{tabular}{llr}
\hline Type of test & \multicolumn{1}{c}{ Null hypothesis } & Probability value \\
\hline Serial correlation $^{\mathrm{a}}$ & No serial correlation up to lag order five & 0.2370 \\
Heteroscedasticity $^{\mathrm{b}}$ & Homoscedasticity & 0.5880 \\
ARCH $^{\mathrm{c}}$ & No ARCH up to lag order five & 0.2335 \\
Normality $^{\mathrm{d}}$ & Normality & 0.6761 \\
\hline
\end{tabular}

Source: Author's estimations on the basis of quarterly data obtained from the databases of the National Institute of Statistics, Geography and Information of Mexico (INEGI), The Bank of Mexico, the United States Census Bureau and the consumer price index published by the United States Bureau of Labor Statistics, of the Department of Labor of the United States.

Notes:

a Breusch-Godfrey test for serial correlation up to lag order five.

b White heteroscedasticity tests with two lags and no cross terms.

c Autoregressive Conditional Heteroscedasticity $(\mathrm{ARCH})$ test with five lags.

d Jarque-Bera normality test.

TABLE 7

Chow's test with multiple break-points, 1998-2008

(Null hypothesis: no structural change)

\begin{tabular}{lcll}
$F$-statistic & 0.367037 & Prob. Value F(21,16) & 0.9835 \\
Log likelihood ratio statistic & 17.30142 & Prob. Value Chi-Squared (21) & 0.6927 \\
Wald statistic & 20.44749 & Prob. Value Chi-Squared (21) & 0.4931 \\
\hline
\end{tabular}

Source: Author's estimations on the basis of quarterly data obtained from the databases of the National Institute of Statistics, Geography and Information of Mexico (INEGI), The Bank of Mexico, the United States Census Bureau and the consumer price index published by the United States Bureau of Labor Statistics, of the Department of Labor of the United States.

Note: Break-points in the sample: 2000:03, 2003:02 and 2006:01. 
Source: Author's estimations on the basis of quarterly data obtained from the databases of the National Institute of Statistics, Geography and Information of Mexico (INEGI), The Bank of Mexico, the United States Census Bureau and the consumer price index published by the United States Bureau of Labor Statistics, of the Department of Labor of the United States. Note: All inverse roots lie within the unit circle, so the estimated ARMA process is stationary and invertible.

\section{VI}

\section{Multivariate time-series analysis}

Given the difficulty of identifying the co-integrating equations and the weak exogeneity of manufacturing exports, a generalized VAR (GVAR) model with stationary variables will be estimated. Such a model is specified as follows:

$$
Y_{t}=\mathrm{B}_{0}+\mathrm{B}_{1} Y_{t-1}+\mathrm{B}_{2} Y_{t-2}+, \ldots,+\mathrm{B}_{p} Y_{t-p}+\varepsilon_{t}
$$

where $Y_{t}=\left[\Delta X_{t}, \Delta v_{t}, \Delta W_{t}, \Delta Q_{t}, \Delta E D_{t}, F D I_{t}, R_{t}, \Delta C U_{t}, \Delta O P_{t}\right]^{\prime}$ is a $9 \times 1$ vector of variables, $B_{0}$ is a $9 \times 1$ vector of intercept terms, and $\left\{B_{i}, i=1,2, \ldots, \mathrm{p}\right\}$ are $9 \times 9$ coefficient matrices. Moreover, $\boldsymbol{\varepsilon}_{t}$ stands for a $9 \times 1$ vector of innovations that behaves according to the following assumptions: $E\left(\varepsilon_{t}\right)=0$ and $E\left(\varepsilon_{t} \varepsilon_{t}^{\prime}\right)=\Lambda$ for every $t$, where $\Lambda=\left\{\sigma_{i j}, i, j=1,2, \ldots, 9\right\}$ is a nondiagonal positive definite matrix, and $E\left(\varepsilon_{t} \varepsilon_{t}{ }^{\prime}\right)=0$ for every $t$ and $s, t \neq s$, in the set $1, \ldots, \mathrm{T}$. We can also view as being multivariate normally distributed, given the test results shown below. ${ }^{17}$

Since the covariance matrix of innovations $(\Lambda)$ is non-diagonal, the elements of $\varepsilon_{t}$ are "contemporaneously" correlated. Sims (1980) uses a Cholesky decomposition of matrix $\Lambda$ to orthogonalize the VAR residuals; but the resulting impulse response functions and variance decompositions are sensitive to the ordering of the equations in the VAR model. The problem lies in the decomposition technique, which

\footnotetext{
${ }^{17}$ Put briefly, it can be said that $\varepsilon_{t} \sim N_{9}(0, \Lambda)$ and is free from serial correlation. In principle, VAR residuals are uncorrelated across time but they are not uncorrelated across equations.
}

is recursive rather than structural. This produces an asymmetric structure, where a shock to a given variable will have a contemporaneous effect on that variable and those that follow it in the ordering. The variables that lead the hypothetical ordering, in contrast, will be affected only through the VAR lag structure. ${ }^{18}$

The generalized impulse-response function approach, developed by Pesaran and Shin (1998), does not have this drawback and can be used to construct an orthogonal set of innovations that is invariant to the ordering of the variables in the VAR model. For expositional convenience, a first-order VAR model is posited first:

$$
Y_{t}=\mathrm{B}_{0}+\mathrm{B}_{1} Y_{t-1}+\varepsilon_{t}
$$

Next, we need to assume that all the inverse roots of the characteristic autoregressive polynomial (in other words, all the roots of $\left|I_{9}-\sum_{i=1}^{P} \mathrm{~B}_{i} L^{i}\right|=0$, where $L$ is the lag operator) lie within the unit circle, so the stability condition is satisfied. Equation (4) can then be rewritten as an infinite moving-average representation:

$$
Y_{t}=\mu+\sum_{i=0}^{\infty} \mathrm{B}_{1}^{i} \varepsilon_{t-i}
$$

where $\mu=\left(I_{9}-A_{1}\right)^{-1} \mathrm{~B}_{0}$ stands for the mean of the process.

18 Generally, a shock to $Y_{i t}$ will have a contemporaneous impact on $Y_{j t}$ only if $j \neq i$. 
According to Pesaran and Shin (1998), an impulse-response function can be interpreted as the difference between the expected value of a variable at time $t+n$, resulting from a shock that occurred at time $t$, and its expected value at time $t+n$ in the absence of such a shock. The expected value is derived from the economy's known history up to time $t-1$. For instance, assuming that a magnitude- $\delta$ shock affects the $j$ th equation of vector $Y_{t}$, then the vector of Generalized Impulse Response Functions (GIRF) is given by:

$$
\begin{gathered}
\operatorname{GIRF}_{Y}\left(n, \delta, \Omega_{t-1}\right)=E\left(Y_{t+n} \mid \varepsilon_{j t}=\delta, \Omega_{t-1}\right)- \\
E\left(Y_{t+n} \mid \Omega_{t-1}\right)
\end{gathered}
$$

where the matrix $\Omega_{t-1}$ represents all available information on the economy's history up to time $t$-1. Combining (6) and (5) it can be inferred that $\operatorname{GIRF}_{Y}\left(n, \delta, \Omega_{t-1}\right)=\mathrm{B}_{1}^{n} \delta$. Under the previously stated assumption that the vector of innovations $\left(\varepsilon_{t}\right)$ is multivariate normally distributed, both Pesaran and Shin (1998) and Koop et al. (1996) show that:

$$
E\left(\varepsilon_{t} \mid \varepsilon_{j t}=\delta\right)=\left(\sigma_{1 j}, \sigma_{2 j}, \ldots, \sigma_{9 j}\right)^{\prime} \sigma_{j j}^{-1} \delta=\Lambda e_{j} \sigma_{j j}^{-1} \delta
$$

where $e_{j}$ is a hypothetical (9x1) vector of innovations with 1 in the $j$ th row and zeros everywhere else. Consequently, the unscaled GIRF vector is given by:

$$
\left(\frac{\mathrm{B}_{1}^{n} \Lambda e_{j}}{\sqrt{\sigma_{j j}}}\right)\left(\frac{\delta}{\sqrt{\sigma_{j j}}}\right)
$$

Lastly, deriving the scaled GIRF vector, denoted $\psi_{j}^{G}(n)$, simply means setting $\delta=\sqrt{\sigma_{j j}}$. That is,

$$
\psi_{j}^{G}(n)=\left(\frac{\mathrm{B}_{1}^{n} \Lambda e_{j}}{\sqrt{\sigma_{j j}}}\right)
$$

Note that $\psi_{j}^{G}(n)$ measures the effect of a onestandard-deviation shock to the $j$ th equation. Such a shock takes place at time $t$ and affects the expected values of vector $Y$ at time $t+n$, where $n=0,1,2, \ldots$, .

\section{Empirical model}

For the purpose of building an adequate empirical model a variety of specifications were tested, not only for the data set (the number and choice of variables in the system) but also for the lag structure of the model. The lag length of a VAR model is critical because the behaviour of the residuals and empirical results are sensitive to the order of the model (in other words the number of lags chosen). Moreover, there are complex trade-offs between the number of lags and the dimension of the VAR model. Thus, after using different lag-length selection criteria (and different parameterizations), the conclusion was that one lag for each variable in each equation allows for adequate dynamic adjustment and efficient estimation, since it is the smallest number of lags producing well-behaved residuals.

By the same token, the trade-off relationships between the data set and the model's lag structure led to the exclusion of wages, FDI and the interest rate. The rationale for excluding such variables is twofold: firstly, shocks to these three variables do not produce statistically significant impulse-response functions; and secondly, their inclusion generates serial correlation and departures from normality in the VAR residuals, which could not be solved through alternative lag structures and/or the use of dummy variables. In this perspective, the final specification is a six-variable VAR model: $Y_{t}=\left[\Delta X_{t}, \Delta v_{t}, \Delta Q_{t}, \Delta E D_{t}, \Delta C U_{t}, \Delta O P_{t}\right]^{\prime}$. The VAR parameter estimates are shown in appendix 3 .

\section{Testing for model adequacy}

As we shall see, a one-lag VAR model with the previous specification (or set of variables) eliminates serial correlation, heteroscedasticity and departures from normality in the VAR residuals. It will also be shown that this particular specification satisfies the stability condition. Table 9 shows the results of the multivariate serial correlation LM tests. The LM statistics and their corresponding $p$-values suggest the absence of serial correlation up to lag order five. ${ }^{19}$

Moreover, the multivariate version of the White heteroscedasticity test indicates that the null hypothesis of homoscedasticity cannot be rejected in any of the cases, at either the $5 \%$ or the $10 \%$ significance levels. See table 10 for further details.

19 We also estimated the matrix of pair-wise cross-correlograms (with two-standard error bounds) for the VAR residuals, which are broadly consistent with the absence of autocorrelation. 
TABLE 9

Multivariate serial correlation LM Tests, 1998-2008

(Null hypothesis: there is no serial correlation at lag order (p))

\begin{tabular}{ccc}
\hline Lag order $(p)$ & LM-Statistics & Prob. \\
\hline 1 & 34.55223 & 0.5375 \\
2 & 46.14492 & 0.1198 \\
3 & 34.80235 & 0.5255 \\
4 & 30.63705 & 0.7213 \\
5 & 38.66307 & 0.3503 \\
\hline
\end{tabular}

Source: Author's estimations on the basis of quarterly data obtained from the databases of the National Institute of Statistics, Geography and Information of Mexico (INEGI), The Bank of Mexico, the United States Census Bureau and the consumer price index published by the United States Bureau of Labor Statistics, of the Department of Labor of the United States.

Note: Probabilities from the Chi-Squared distribution with 49 degrees of freedom.

LM: Lagrange multiplier.

TABLE 10

White heteroscedasticity tests for VAR residuals, 1998-2008

(Null hypothesis: homoscedasticity)

\begin{tabular}{|c|c|c|c|c|c|}
\hline \multicolumn{6}{|c|}{ Joint test } \\
\hline \multicolumn{2}{|c|}{ Chi-Squared statistic $\left(\chi^{2}\right)$} & \multicolumn{2}{|c|}{ Degrees of freedom } & \multicolumn{2}{|c|}{ Prob. } \\
\hline \multicolumn{2}{|c|}{270.2510} & \multicolumn{2}{|c|}{252} & \multicolumn{2}{|c|}{0.2051} \\
\hline \multicolumn{6}{|c|}{ Individual components } \\
\hline Dependent & $\mathrm{R}$-squared & $\mathrm{F}(12,31)$ & Prob. & Chi-sq(12) & Prob. \\
\hline res1*res1 & 0.240216 & 0.816754 & 0.6323 & 10.56949 & 0.5661 \\
\hline res $2 *$ res 2 & 0.255522 & 0.886659 & 0.5688 & 11.24296 & 0.5082 \\
\hline res $3 *$ res 3 & 0.320257 & 1.217121 & 0.3155 & 14.09129 & 0.2949 \\
\hline res $4 *$ res 4 & 0.367625 & 1.501792 & 0.1763 & 16.17548 & 0.1833 \\
\hline res $5 *$ res 5 & 0.386347 & 1.626431 & 0.1351 & 16.99928 & 0.1496 \\
\hline res6*res6 & 0.346877 & 1.372021 & 0.2312 & 15.26259 & 0.2274 \\
\hline res $2 *$ res 1 & 0.176493 & 0.553658 & 0.8613 & 7.765701 & 0.8032 \\
\hline res $3 *$ res 1 & 0.255840 & 0.888144 & 0.5675 & 11.25697 & 0.5070 \\
\hline res $3 *$ res 2 & 0.163653 & 0.505496 & 0.8951 & 7.200735 & 0.8441 \\
\hline res $4 *$ res 1 & 0.349548 & 1.388266 & 0.2236 & 15.38013 & 0.2213 \\
\hline res $4 *$ res 2 & 0.375232 & 1.551532 & 0.1587 & 16.51019 & 0.1690 \\
\hline res $4 *$ res 3 & 0.233105 & 0.785227 & 0.6613 & 10.25661 & 0.5935 \\
\hline res5*res 1 & 0.340077 & 1.331262 & 0.2512 & 14.96337 & 0.2434 \\
\hline res5*res2 & 0.336725 & 1.311480 & 0.2615 & 14.81589 & 0.2517 \\
\hline $\operatorname{res} 5^{*}$ res 3 & 0.181716 & 0.573681 & 0.8462 & 7.995512 & 0.7855 \\
\hline res $5^{*}$ res 4 & 0.386454 & 1.627160 & 0.1349 & 17.00396 & 0.1494 \\
\hline
\end{tabular}

Source: Author's estimations on the basis of quarterly data obtained from the databases of the National Institute of Statistics, Geography and Information of Mexico (INEGI), The Bank of Mexico, the United States Census Bureau and the consumer price index published by the United States Bureau of Labor Statistics, of the Department of Labor of the United States.

Note: The test was performed with levels and squares only (no cross terms were included).

Res: residuals. 
Table 11 shows the outcome of the multivariate normality tests. The Jarque-Bera statistics and related probability values indicate that, by and large, VAR residuals follow a multivariate normal distribution.

To show that the model satisfies the stability condition, the "inverse roots" of the characteristic autoregressive polynomial were calculated. As reported in table 12, all such roots have an absolute value (modulus) of less than 1 and lie within the unit circle, meaning that the "overall" model is stable and hence stationary. In conclusion, the estimated VAR model is adequate, since the residuals are well-behaved and the lag structure is stable.

\section{Generalized impulse-response functions}

In this subsection a set of twelve-month impulseresponse functions with $95 \%$ confidence intervals are presented, which depict the dynamic response of manufacturing exports to innovations in the different system variables. Each innovation (or shock) should be understood here as a one-standard-deviation increase in the variable in question, which is unexpected and transitory since it lasts for one period only. Moreover, the responses are generalized in that they do not depend on the VAR orderings, and the confidence bands are useful for establishing statistical significance. In other
TABLE 12

Stability condition test, 1998-2008

(Inverse roots of characteristic autoregressive polynomial)

\begin{tabular}{ll}
\hline Root & Modulus \\
\hline 0.788565 & 0.788565 \\
0.364357 & 0.364357 \\
$-0.263775-0.217130 \mathrm{i}$ & 0.341647 \\
$-0.263775+0.217130 \mathrm{i}$ & 0.341647 \\
0.153255 & 0.153255 \\
0.000574 & 0.000574 \\
\hline
\end{tabular}

Source: Author's estimations on the basis of quarterly data obtained from the databases of the National Institute of Statistics, Geography and Information of Mexico (INEGI), The Bank of Mexico, the United States Census Bureau and the consumer price index published by the United States Bureau of Labor Statistics, of the Department of Labor of the United States.

Note: All inverse roots have an absolute value (modulus) $<1$, so the stability condition is fulfilled.

words, the impulse-response function is statistically significant at the 5\% level only in the period for which the confidence interval excludes the value zero (see figure 1).

As shown in figure 1, a positive labour-productivity shock raises manufacturing exports upon impact, but the effect fades around the second month. In contrast, a real depreciation of the domestic currency

\begin{tabular}{|c|c|c|c|}
\hline \multicolumn{4}{|c|}{ Joint test } \\
\hline Jarque-Bera statistic & \multicolumn{2}{|c|}{ Degrees of freedom } & Prob. \\
\hline 12.11528 & \multicolumn{2}{|c|}{12} & 0.4365 \\
\hline \multicolumn{4}{|c|}{ Individual components } \\
\hline Component & Jarque-Bera Statistic & Degrees of freedom & Prob. \\
\hline$\Delta X_{t}$ & 0.145183 & 2 & 0.9300 \\
\hline$\Delta v_{t}$ & 2.580443 & 2 & 0.2752 \\
\hline$\Delta Q_{t}$ & 2.407762 & 2 & 0.3000 \\
\hline$\Delta E D_{t}$ & 1.878920 & 2 & 0.3908 \\
\hline$\Delta C U_{t}$ & 0.954520 & 2 & 0.6205 \\
\hline$\Delta O P_{t}$ & 4.148453 & 2 & 0.1257 \\
\hline
\end{tabular}

Source: Author's estimations on the basis of quarterly data obtained from the databases of the National Institute of Statistics, Geography and Information of Mexico (INEGI), The Bank of Mexico, the United States Census Bureau and the consumer price index published by the United States Bureau of Labor Statistics, of the Department of Labor of the United States.

H. Lütkepohl, New Introduction to Multiple Time Series Analysis, Nueva York, Springer-Verlag, 2006.

Note: The Cholesky Orthogonalization method was used (Lütkepohl, 2006: 174-181). 
Export shock

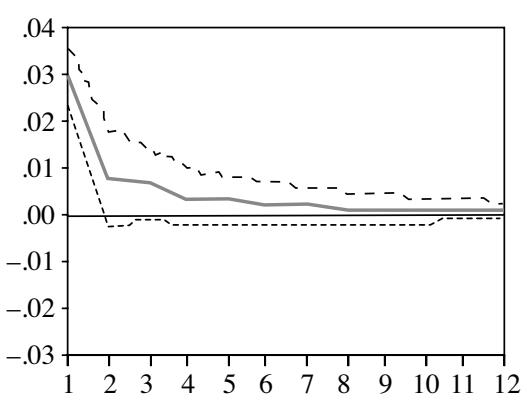

External demand shock

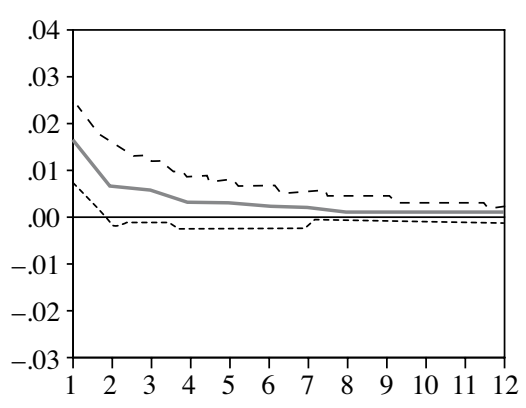

Labor productivity shock

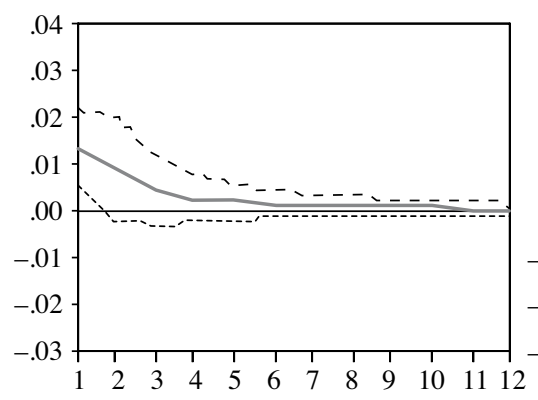

Capacity utilization shock

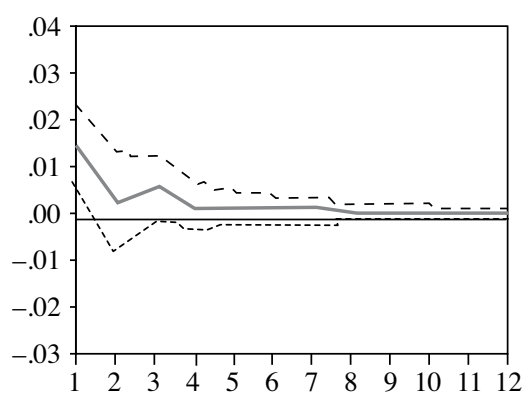

Real exchange rate shock

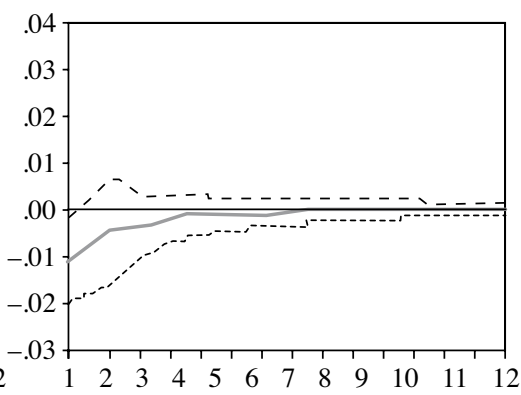

Occupied personnel shock

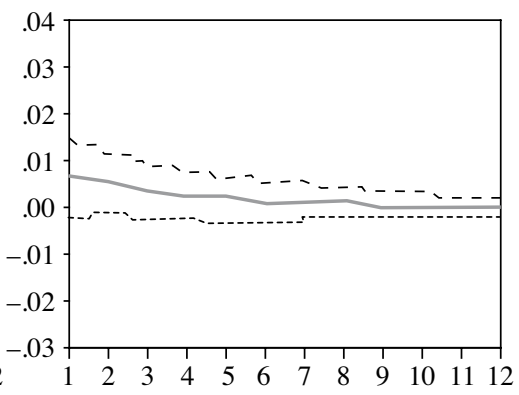

Source: Author's estimations on the basis of quarterly data obtained from the databases of the National Institute of Statistics, Geography and Information of Mexico (INEGI), The Bank of Mexico, the United States Census Bureau and the consumer price index published by the United States Bureau of Labor Statistics, of the Department of Labor of the United States.

reduces the volume of exports, although this effect does not persist over time. As the reader may recall, these two findings are consistent with the univariate time-series results reported in table 5. As noted above, real exchange-rate depreciation affects exports through both demand- and supply-side channels. On the demand side it makes exports cheaper in terms of foreign currency, thereby strengthening international competitiveness; but, on the supply side, it raises the local-currency cost of imported capital goods and intermediate inputs, which inevitably undermines international competitiveness. Following this line of reasoning, the empirical evidence suggests that the net effect of a real depreciation on international competitiveness and exports is negative, at least in the short term.

External-demand shocks boost manufacturing exports, although the positive effect dissipates around the second month. Lastly, capacity-utilization shocks increase rather than reduce exports, which is consistent with the self-selection hypothesis in the sense that manufacturing firms make a conscious effort to sell in foreign markets. ${ }^{20}$

\footnotetext{
${ }^{20}$ In contrast, a rise in capacity utilization resulting from higherthan-expected domestic demand would be consistent with a declining trend in exports.
} 


\section{VII}

\section{Implications for economic policy}

The estimation results consistently indicate that manufacturing exports respond positively not only to external demand but also to labour productivity. According to the elasticities obtained from the estimated structural ARIMA model, labour productivity has a larger impact on exports than external demand. Nonetheless, the impulse-response functions resulting from the GVAR model suggest that external demand is slightly more influential than worker productivity. In any event, labour productivity seems to be one of the key determinants of manufacturing exports; so a relevant economic-policy implication is that an external demand contraction (brought about by an international recession) could, to some extent, be offset by increasing worker productivity.

In this context, Mexico needs to develop a comprehensive, coherent and cost-effective policy package to enhance labour productivity in the manufacturing sector. This package should encompass temporary training programmes to develop certain skills at critical junctures (especially among the unemployed, to enable them to meet employers' demands in difficult times), along with continuous training programmes aimed at career advancement.

There are many empirical results showing that appropriate job-related training and quality formal schooling can yield significant productivity gains. ${ }^{21}$ Generally speaking, education provides knowledge, skills and abilities that are useful in terms of raising wages, output per worker, and output per labourhour. Notwithstanding the importance of education for coping with knowledge-based competition in the global marketplace, employment-related training courses are more likely to be successful as a short-term countercyclical measure in an international economic slowdown..$^{22}$ In other words, without diverting resources from longer-term human capital development through

\footnotetext{
21 Authors such as Bartel (1992), Mincer (1994), Black and Lynch (1996), Dearden et al. (2005), Mungaray and Ramírez (2007), and Padilla and Juárez (2006) reach this conclusion on the basis of different productivity measures.

22 According to Maglen (1995), training is more specific and more contemporaneously correlated with work-place performance, whereas education is more general and is usually imparted before (often long before) the individual in question joins the labour market.
}

the formal education system, the Government could (in conjunction with other initiatives) intensify efforts through a wide range of training programmes to counterbalance lower-than-expected external demand for Mexican manufactures.

In this regard, it is essential to properly identify and categorize specific training needs, not only in the Mexican manufacturing sector as a whole but in every subsector and industry group. The underlying principle is that the content of training (which needs to target the correct knowledge, skills and abilities on a case-by-case basis) may prove to be as important as the amount of training provided to the workforce. Moreover, as employers' demands evolve along with technological change and innovation, an accurate follow-up system needs to be set up to gather precise information on new training requirements and future labour-market trends. Complementary research is needed to assess the effects of different types of training on workers' productivity: on-the-job/offthe-job, workshops, courses, training plans, and so forth. Black and Lynch (1996), for example, argue that off-the-job training may have a larger impact on productivity than on-the-job training, since workers who are trained outside the factory may be receiving more advanced skills. In short, a research endeavour of this sort could yield valuable insights into the right mix of policy instruments to cope with sudden slumps in external demand, thereby making labour-market policies more appropriate and effective.

More thorough knowledge of training-related productivity gains may also identify a framework for setting and attaining longer-term programmatic targets, in a joint effort involving all relevant stakeholders, including workers, employers, public- and privatesector training providers, sector bodies, and the like. As a final comment, even though short- and longterm labour-market policies should be designed and implemented in an integrated way, the econometric work and findings described in this paper basically relate to short-run policy-making.

Another critical issue concerns the adverse effects of real exchange-rate depreciation on manufacturing exports. As noted above, this evidence is consistent with the view that exchange-rate movements influence not only the demand side but also the supply side. In 
such circumstances, the negative impact on exports of real currency-depreciation reflects the heavy reliance of manufacturing firms on foreign suppliers, mainly of intermediate inputs for which the local-currency cost rises as the Mexican peso weakens against the dollar. A well-known policy recommendation, which has had limited success thus far, is to improve productive

\section{VIII \\ Conclusions}

This article has evaluated various determinants of Mexican manufacturing exports using two complementary econometric approaches: (i) the univariate time series approach, which makes it possible to estimate elasticities; and (ii) the generalized VAR approach, which provides a fully dynamic perspective by estimating impulse-response functions. Model adequacy was ensured in both cases through specification, residual and stability tests. The testing tools used varied according to the nature of each econometric modelling method.

As some of the findings are robust to changes in the econometric methodology used, two solid conclusions can be reached. Firstly, manufacturing exports are positively related to labour productivity and external demand. Secondly, real exchange-rate depreciation reduces rather than increases manufacturing exports, at least in the short term. This evidence is consistent with the notion that the Mexican economy is highly dependent on imported capital and intermediate goods. Consequently, real currency depreciation generates not only demand-side but also strong supply-side effects. On the demand side, it makes manufacturing exports cheaper in terms of foreign currency, and therefore strengthens international competitiveness. On the supply side, however, it raises the local-currency cost capacity and efficiency in the import-substituting sector, with a view to reducing the import content of manufactured goods. Moreover, to raise the domestic content of manufactures, additional and more efficient production chains need to be formed and consolidated -between large manufacturing exporters and small and medium-sized local businesses. of imported intermediate inputs, thereby weakening international competitiveness. The empirical results show that the negative (supply-side) effects tend to dominate in the short run.

It is worth recalling that manufacturing exports display a positive relationship with occupied personnel under the univariate analysis, and with capacity utilization under the multivariate analysis. This was found to be consistent with the self-selection hypothesis in the sense that firms make a conscious effort to sell in foreign markets. Since a firm's desire to export determines many investment and production decisions, higher capacity utilization may lead to an increase (rather than a decrease) in manufacturing exports.

Two important economic policy implications can be drawn from this study. Firstly, real exchangerate depreciation may worsen rather than improve export performance in the short term. Secondly, a comprehensive and coherent package to enhance labour productivity could significantly increase manufacturing exports. Moreover, the adverse effects of an international recession on Mexican exports could, to some degree, be offset by raising worker productivity. Thus, in the face of a recession in the United States it might be advantageous for Mexico to invest more in training and education. 
APPENDIX 1

TABLE A1

Description of data sources and measurement units

Statistical Series

Manufacturing exports quantity Index of $(X)$.

Manufacturing industry labour productivity index ( $)$.

Real effective exchange rate index $(Q)$

External demand for Mexican manufacturing exports (ED), measured by a quantity index of total U.S. manufacturing imports.

Real foreign direct investment (FDI).

Cost of domestic credit, as measured by the weighted average of real interest rates on commercial paper $(R)$.

Percentage capacity utilization in manufacturing industry $(C U)$.

Index of occupied personnel in manufacturing industry $(O P)$.

\section{Source}

National Institute of Statistics, Geography and Informatics of Mexico (INEGI).

INEGI.

Banco de México.

United States Census Bureau.

Ministry of the Economy. The price index used as a deflator was the Consumer Price Index published by the United States Bureau of Labor Statistics.

INEGI.

INEGI.

INEGI.

Source: Prepared by the author.

Notes:

1. Time interval: January 1998-December 2008.

2. Frequency: Quarterly. 
APPENDIX 2

A VEC model is a VAR model that is restricted to account for one or more co-integrating relations. Equation (3) can thus be re-parameterized to express the following VEC model:

$$
\begin{gathered}
\Delta Y_{t}=\mathrm{B}_{0}+\Pi Y_{t-1}+\Gamma_{1} \Delta Y_{t-1}+ \\
\Gamma_{2} \Delta Y_{t-2}+, \ldots,+\Gamma_{(p-1)} \Delta Y_{t-(p-1)}+\varepsilon_{t}
\end{gathered}
$$

where $\Pi=\sum_{i=1}^{p} \mathrm{~B}_{i}-I$ and $\Gamma_{i}=-\sum_{j=i+1}^{p} \mathrm{~B} j$. The fourth implication of the Granger Representation Theorem (Engle and Granger, 1987) establishes that if a $k$-dimensional vector of $\mathrm{I}(1)$ variables involves one or more co-integrating relations, then a VEC model exists that can be correctly represented by the above equation. Formally, if the variables in vector $Y_{t}$ are I(1) and the rank of the coefficient matrix $\Pi$ (denoted $r$ ) is small (that is, if $r<k$ ), then it can be shown that $k x r$ matrices $\alpha$ and $\beta$ (both with rank $r$ ) exist, such that (i) $\Pi=\alpha \beta^{\prime}$ and (ii) $\beta^{\prime} Y_{t-1}$ is a stationary system. Similarly, since each column of $\beta$ is a co-integrating vector, it can be stated that $\beta^{\prime} Y_{t-1}$ contains the $r$ long-run equilibrium relations among the $k$ variables. Such long-run relations in $\beta^{\prime} Y_{t-1}$ are expressed in the form of error-correction terms (ECT). The matrix $\alpha$, on the other hand, contains the adjustment or short-run coefficients of the VEC model, the values of which determine the speed at which equilibrium is restored following a disturbance. The purpose of capturing the short-run dynamics is also served by coefficient matrices $\Gamma_{1}, \Gamma_{2}, \ldots, \Gamma_{(p-1)}$.

In this context, if we assume that $\beta^{\prime} Y_{t-1}$ contains two cointegrating relations (denoted ECT $1_{t-1}$ and ЕСT $2_{t-1}$, respectively), as the largest-eigenvalue tests suggest, then the resulting matrix of estimated adjustment coefficients is the following:

TABLE A2

Matrix of estimated adjustment coefficients

\begin{tabular}{|c|c|c|}
\hline Equation & $E C T 1_{t-1}$ & $E C T 2_{t-1}$ \\
\hline$\Delta X_{t}$ & $\begin{array}{l}0.071304 \\
(0.23407) \\
{[0.30462]}\end{array}$ & $\begin{array}{c}-0.313378 \\
(0.97010) \\
{[-0.01840]}\end{array}$ \\
\hline$\Delta v_{t}$ & $\begin{array}{l}0.306825^{* * *} \\
(0.06186) \\
{[4.95999]}\end{array}$ & $\begin{array}{l}-1.275998 * * * \\
(0.25639) \\
{[-4.99358]}\end{array}$ \\
\hline$\Delta W_{t}$ & $\begin{array}{c}0.248226 \\
(0.20551) \\
{[1.20785]}\end{array}$ & $\begin{array}{c}-1.01029 \\
(0.85173) \\
{[-1.16447]}\end{array}$ \\
\hline$\Delta Q_{t}$ & $\begin{array}{l}-0.503782 \\
(0.35069) \\
{[-2.60101]^{* *}}\end{array}$ & $\begin{array}{l}2.097696 \\
(1.45342) \\
{[1.44328]}\end{array}$ \\
\hline$\Delta E D_{t}$ & $\begin{array}{c}-0.236342 \\
(0.19946) \\
{[-0.92653]}\end{array}$ & $\begin{array}{l}0.965415 \\
(0.82666) \\
{[1.16785]}\end{array}$ \\
\hline$\Delta C U_{t}$ & $\begin{array}{c}-1.010744 \\
(4.77390) \\
{[-0.32095]}\end{array}$ & $\begin{array}{c}2.609343 \\
(19.7853) \\
{[0.13188]}\end{array}$ \\
\hline$\Delta O P_{t}$ & $\begin{array}{c}0.017312 \\
(0.03268) \\
{[0.52974]}\end{array}$ & $\begin{array}{c}-0.068394 \\
(0.13544) \\
{[-0.50498]}\end{array}$ \\
\hline
\end{tabular}
(The $\alpha$ matrix)

Source: Author's estimations on the basis of quarterly data obtained from the databases of the National Institute of Statistics, Geography and Information of Mexico (INEGI), The Bank of Mexico, the United States Census Bureau and the consumer price index published by the United States Bureau of Labor Statistics, of the Department of Labor of the United States.

Notes: Standard errors in ( ) and $t$-statistics in [ ].

Asterisks $* * *$ and $* * *$ denote significance at the $10 \%, 5 \%$ and $1 \%$ levels, respectively.

The results shown in table A2 indicate that none of the adjustment parameters is statistically significant in the export equation $\left(\Delta X_{t}\right)$, which is why manufacturing exports were found to be weakly exogenous with respect to the $\alpha$ matrix. 
APPENDIX 3

TABLE A3

Parameter estimates for the final VAR model specification

\begin{tabular}{|c|c|c|c|c|c|c|}
\hline & $\Delta X_{t}$ & $\Delta v_{t}$ & $\Delta Q_{t}$ & $\Delta E D_{t}$ & $\Delta C U_{t}$ & $\Delta O P_{t}$ \\
\hline$\Delta X_{t-1}$ & $\begin{array}{c}0.188165 \\
(0.22829) \\
{[0.82422]}\end{array}$ & $\begin{array}{c}0.044354 \\
(0.08525) \\
{[0.52026]}\end{array}$ & $\begin{array}{c}-0.203017 \\
(0.37362) \\
{[-0.54338]}\end{array}$ & $\begin{array}{c}0.251443 \\
(0.20776) \\
{[1.21028]}\end{array}$ & $\begin{array}{c}2.977106 \\
(6.74198) \\
{[0.44158]}\end{array}$ & $\begin{array}{c}0.053435 \\
(0.03536) \\
{[1.51128]}\end{array}$ \\
\hline$\Delta \mathrm{v}_{t-1}$ & $\begin{array}{r}0.807990 \\
(0.53519) \\
{[1.50973]}\end{array}$ & $\begin{array}{c}-0.019072 \\
(0.19986) \\
{[-0.09543]}\end{array}$ & $\begin{array}{c}1.035099 \\
(0.87588) \\
{[1.18178]}\end{array}$ & $\begin{array}{c}1.476432 \\
(0.48704) \\
{[3.03144]}\end{array}$ & $\begin{array}{c}31.52161 \\
(15.8052) \\
{[1.99439]}\end{array}$ & $\begin{array}{c}0.040187 \\
(0.08289) \\
{[0.48484]}\end{array}$ \\
\hline$\Delta Q_{t-1}$ & $\begin{array}{c}-0.044268 \\
(0.12766) \\
{[-0.34678]}\end{array}$ & $\begin{array}{c}-0.000724 \\
(0.04767) \\
{[-0.01519]}\end{array}$ & $\begin{array}{c}0.058313 \\
(0.20892) \\
{[0.27912]}\end{array}$ & $\begin{array}{c}0.032161 \\
(0.11617) \\
{[0.27684]}\end{array}$ & $\begin{array}{c}2.393695 \\
(3.76994) \\
{[0.63494]}\end{array}$ & $\begin{array}{c}-0.027179 \\
(0.01977) \\
{[-1.37470]}\end{array}$ \\
\hline$\Delta E D_{t-1}$ & $\begin{array}{c}0.114752 \\
(0.22154) \\
{[0.51797]}\end{array}$ & $\begin{array}{c}0.015873 \\
(0.08273) \\
{[0.19186]}\end{array}$ & $\begin{array}{c}0.366712 \\
(0.36257) \\
{[1.01143]}\end{array}$ & $\begin{array}{r}0.137367 \\
(0.20161) \\
{[0.68135]}\end{array}$ & $\begin{array}{r}2.527265 \\
(6.54251) \\
{[0.38628]}\end{array}$ & $\begin{array}{r}0.018223 \\
(0.03431) \\
{[0.53110]}\end{array}$ \\
\hline$\Delta C U_{t-1}$ & $\begin{array}{c}-0.009063 \\
(0.00671) \\
{[-1.35024]}\end{array}$ & $\begin{array}{c}0.001414 \\
(0.00251) \\
{[0.56414]}\end{array}$ & $\begin{array}{c}-0.003511 \\
(0.01099) \\
{[-0.31962]}\end{array}$ & $\begin{array}{c}-0.001987 \\
(0.00611) \\
{[-0.32534]}\end{array}$ & $\begin{array}{c}-0.305305 \\
(0.19823) \\
{[-1.54018]}\end{array}$ & $\begin{array}{c}-0.000396 \\
(0.00104) \\
{[-0.38058]}\end{array}$ \\
\hline$\Delta O P_{t-1}$ & $\begin{array}{c}1.209608 \\
(0.80273) \\
{[1.50687]}\end{array}$ & $\begin{array}{c}-0.230256 \\
(0.29977) \\
{[-0.76810]}\end{array}$ & $\begin{array}{c}-1.264143 \\
(1.31373) \\
{[-0.96226]}\end{array}$ & $\begin{array}{c}0.329078 \\
(0.73051) \\
{[0.45048]}\end{array}$ & $\begin{array}{c}1.342715 \\
(23.7061) \\
{[0.05664]}\end{array}$ & $\begin{array}{r}0.640945 \\
(0.12432) \\
{[5.15549]}\end{array}$ \\
\hline $\mathrm{C}$ & $\begin{array}{c}0.005182 \\
(0.00909) \\
{[0.57002]}\end{array}$ & $\begin{array}{c}0.005044 \\
(0.00340) \\
{[1.48552]}\end{array}$ & $\begin{array}{c}-0.019301 \\
(0.01488) \\
{[-1.29715]}\end{array}$ & $\begin{array}{c}0.005365 \\
(0.00827) \\
{[0.64842]}\end{array}$ & $\begin{array}{c}-0.262657 \\
(0.26850) \\
{[-0.97824]}\end{array}$ & $\begin{array}{r}-0.003210 \\
(0.00141) \\
{[-2.27948]}\end{array}$ \\
\hline$\overline{R^{2}}$ & 0.254138 & 0.049825 & 0.092319 & 0.373294 & 0.157935 & 0.672209 \\
\hline Adjusted $R^{2}$ & 0.118527 & -0.122934 & -0.072714 & 0.259347 & 0.004833 & 0.612611 \\
\hline
\end{tabular}

Source: Author's estimations on the basis of quarterly data obtained from the databases of the National Institute of Statistics, Geography and Information of Mexico (INEGI), The Bank of Mexico, the United States Census Bureau and the consumer price index published by the United States Bureau of Labor Statistics, of the Department of Labor of the United States.

Note: Standard errors in ( ) and t-statistics in [ ].

(Original: English)

\section{Bibliography}

Banco de México (2008), Informe anual 2008 del Banco de México, Mexico City.

Bartel, A. (1992), "Productivity gains from the implementation of employee training programs", NBER Working Papers, No. 3893, Cambridge, Massachusetts, National Bureau of Economic Research.

Bayoumi, T. and B. Eichengreen (1997), "Is regionalism simply a diversion? Evidence from the EC and EFTA", Regionalism versus Multilateral Trade Arrangements, T. Ito and A. Krueger (eds.), Chicago, The University of Chicago Press.

Bergstrand, J. (1985), "The gravity equation in international trade: some microeconomic foundations and empirical evidence", Review of Economics and Statistics, vol. 67, No. 3, Cambridge, Massachusetts, The MIT Press.

Berrettoni, D. and S. Castresana (2007), "Exportaciones y tipo de cambio real: el caso de las manufacturas industriales argentinas", Revista del CEI: comercio exterior e integración, No. 9, Buenos Aires, Centro de Economía Internacional.

Black, S. and L. Lynch (1996), "Human capital investment and productivity", The American Economic Review, vol. 86, No. 2, Nashville, Tennessee, American Economic Association.

Boisso, D. and M. Ferrantino (1997), "Economic distance, cultural distance, and openness in international trade: empirical puzzles", Journal of Economic Integration, vol. 12, Seoul, Sejong University.

Catão, L. and E. Falsetti (2002), "Determinants of Argentina's external trade", Journal of Applied Economics, vol. 5, No. 1, Buenos Aires, CEMA University.

Cuevas, V. (2008), "Efectos de la productividad laboral en las exportaciones manufactureras mexicanas", Comercio exterior, vol. 58, No. 6, Mexico City, Banco Nacional de Comercio Exterior. 
Dearden, L., H. Reed and J.V. Reenen (2005), "The impact of training on productivity and wages: evidence from British panel data”, CEP Discussion Papers, No. 674, London, Centre for Economic Performance.

Dickey, D., W. Bell and R. Miller (1986), "Unit roots in time series models: tests and implications", The American Statistician, vol. 40, Alexandria, Virginia, American Statistical Association.

Dickey, D. and W. Fuller (1981), "Likelihood ratio statistics for autoregressive time series with a unit root", Econometrica, vol. 49, No. 4, Cleveland, Ohio, The Econometric Society.

Engle, R. and C. Granger (1987), "Co-integration and error correction: representation, estimation, and testing", Econometrica, vol. 55, No. 2, Cleveland, Ohio, The Econometric Society.

Goldberg, L. and M. Klein (1997), "Foreign direct investment, trade and real exchange rate linkages in Southeast Asia and Latin America", NBER Working Papers, No. 6344, Cambridge, Massachusetts, National Bureau of Economic Research.

Hamilton, J. (1994), Time Series Analysis, Princeton, Princeton University Press.

Hannan, E. and J. Rissanen (1982), "Recursive estimation of mixed autoregressive-moving average order", Biometrika, vol. 69, No. 1, Oxford, Oxford University Press.

Isard, W. (1954), "Location theory and trade theory: short-run analysis", Quarterly Journal of Economics, vol. 68, No. 2, Cambridge, Massachusetts, The MIT Press.

Jiménez, F., G. Aguilar and J. Kapsoli (1998), "Competitividad en la industria manufacturera peruana" [online] http://www. pucp.edu.pe/departamento/economia/images/documentos/ DDD148.pdf

Johansen, S. (1995), Likelihood-based Inference in Cointegrated Vector Autoregressive Models, Oxford, Oxford University Press.

Koop, G., M. Pesaran and S. Potter (1996), "Impulse response analysis in nonlinear multivariate models", Journal of Econometrics, vol. 74, No. 1, Amsterdam, Elsevier.

Kwiatkowski, D. and others (1992), "Testing the null hypothesis of stationary against the alternative of a unit root", Journal of Econometrics, vol. 54, No. 1-3, Los Angeles, California, John Wiley \& Sons.

Lütkepohl, H. (2006), New Introduction to Multiple Time Series Analysis, New York, Springer-Verlag.

MacKinnon, J. (1996), "Numerical distribution functions for unit root and cointegration tests", Journal of Applied Econometrics, vol. 11, No. 6, Los Angeles, California, John Wiley \& Sons.

MacKinnon, J., A. Haug and L. Michelis (1999), "Numerical distribution functions of likelihood ratio tests for cointegration", Journal of Applied Econometrics, vol. 14, No. 5, Los Angeles, California, John Wiley \& Sons.

Maglen, L. (1995), "The role of education and training in the economy", Working Paper, No. 2, Clayton, Centre for the Economics of Education and Training, Monash University.

Mbaye, A. and S. Golub (2002), "Unit labor cost, international competitiveness, and exports: the case of Senegal", Journal of African Economies, vol. 11, No. 2, Oxford, Oxford University Press.

Mincer, J. (1994), "Investment in U.S. education and training", NBER Working Papers, No. 4844, Cambridge, Massachusetts, National Bureau of Economic Research.

Mortimore, M., S. Vergara and J. Katz (2001), "La competitividad internacional y el desarrollo nacional: implicancias para la política de inversión extranjera directa en América Latina", Desarrollo productivo series, No. 107 (LC/L.1586-P), Santiago, Chile, Economic Commission for Latin America and the Caribbean (ECLAC). United Nations publication, Sales No. S.01.II.G.130.

Mungaray, A. and M. Ramírez (2007), "Capital humano y productividad en microempresas", Investigación económica, vol. 66, No. 260, Mexico City, National Autonomous University of Mexico.

Nabi, I. and M. Luthria (2002), "Building competitiveness: a roadmap and policy guide", Building Competitive Firms Incentives and Capabilities, Washington, D.C., World Bank.

Padilla, R. and M. Juárez (2006), "Efectos de la capacitación en la competitividad de la industria manufacturera", Estudios y perspectivas series, No. 49, Mexico City, ECLAC Subregional Headquarters in Mexico.

Patterson, K. (2000), An Introduction to Applied Econometrics: a Time Series Approach, New York, Palgrave MacMillan.

Perron, P. and S. Ng (1996), "Useful modifications to unit root tests with dependent error and their local asymptotic properties", Review of Economic Studies, vol. 63, No. 3, London, Blackwell Publishing.

Pesaran, M. and Y. Shin (1998), "Generalized impulse response analysis in linear multivariate models", Economic Letters, vol. 58, No. 1, Amsterdam, Elsevier.

Phillips, P. and P. Perron (1988), "Testing for a unit root in time series regression”, Biometrika, vol. 75, No. 2, Oxford, Oxford University Press.

Pöyhönen, P. (1963), "A tentative model for the volume of trade between countries", Review of World Economics, vol. 90, No. 1, Kiel, Schleswig-Holstein.

Reinhart, C. (1995), "Devaluation, relative prices, and international trade: evidence from developing countries", IMF Staff Papers, vol. 42, No. 2, Washington, D.C., International Monetary Fund.

Riedel, J. (1988), "The demand for LDC exports of manufactures: estimates from Hong Kong”, The Economic Journal, vol. 98, No. 389, Royal Economic Society.

Senhadji, A. and C. Montenegro (1998), "Time-series analysis of export demand equations: a cross-country analysis", IMF Working Papers, No. 149, Washington, D.C., International Monetary Fund.

Sims, C. (1980), "Macroeconomics and reality", Econometrica, vol. 48, No. 1, Cleveland, Ohio, The Econometric Society.

Summary, R. (1989), "A political-economic model of U.S. bilateral trade", The Review of Economics and Statistics, vol. 71, No. 1, Cambridge, Massachusetts, The MIT Press.

Tinbergen, J. (1962), "Shaping the world economy-suggestions for an international economic policy", The Twentieth Century Fund, New York. 